The Canadian Mineralogist

Vol. 39, pp. 1131-1138 (2001)

\title{
NEUTRON SPECTROSCOPIC STUDY OF SYNTHETIC ALUNITE AND OXONIUM-SUBSTITUTED ALUNITE
}

\author{
GEORGE A. LAGER ${ }^{\S}$ \\ Department of Geography and Geosciences, University of Louisville, Louisville, Kentucky 40292, U.S.A.
}

GREGG A. SWAYZE

U.S. Geological Survey, Denver Federal Center, Denver, Colorado 80225, U.S.A.

CHUN-KEUNG LOONG, FRANK J. ROTELLA ${ }^{\mathbb{I l}}$ AND JAMES W. RICHARDSON, JR.

IPNS Division, Argonne National Laboratory, Argonne, Illinois 60439, U.S.A.

ROGER E. STOFFREGEN

AWK Consulting Engineers, 1225 Rodi Road, Turtle Creek, Pennsylvania 15145, U.S.A.

\begin{abstract}
Synthetic, polycrystalline samples of alunite $\left[\mathrm{K}_{0.88}\left(\mathrm{H}_{3} \mathrm{O}\right)_{0.12} \mathrm{Al}_{2.64}\left(\mathrm{SO}_{4}\right)_{2}(\mathrm{OH})_{4.92}\left(\mathrm{H}_{2} \mathrm{O}\right)_{1.08}\right]$ and oxonium-substituted alunite $\left[\mathrm{H}_{3} \mathrm{OAl}_{2.87}\left(\mathrm{SO}_{4}\right)_{2}(\mathrm{OH})_{5.61}\left(\mathrm{H}_{2} \mathrm{O}\right)_{0.39}\right]$ have been investigated using incoherent, inelastic neutron-scattering (IINS) methods in order to determine the nature of the non-OH " $\mathrm{H}_{2} \mathrm{O}$ ". IINS measurements were made on non-deuterated samples at $20 \mathrm{~K}$ using the HRMECS chopper spectrometer with 250 and $600 \mathrm{meV}$ incident energies. Alunite and oxonium-substituted alunite exhibit similar spectral features over the energy range of $120-550 \mathrm{meV}$, where assignments for local vibrations can be made based on the presence of $\mathrm{OH}$ and $\mathrm{H}_{2} \mathrm{O}$ groups. Salient differences in the intensities and positions of the observed low-energy vibrational bands reflect the effects of chemical substitution on the structural environment of the monovalent cation site and neighboring $\mathrm{Al}$ and $\mathrm{OH}$ sites in the framework.
\end{abstract}

Keywords: alunite, inelastic neutron scattering, crystal structure, oxonium ion.

\section{SOMMAIRE}

Nous avons étudié des échantillons synthétiques polycristallins d'alunite $\left[\mathrm{K}_{0.88}\left(\mathrm{H}_{3} \mathrm{O}\right)_{0.12} \mathrm{Al}_{2.64}\left(\mathrm{SO}_{4}\right)_{2}(\mathrm{OH})_{4.92}\left(\mathrm{H}_{2} \mathrm{O}\right)_{1.08}\right]$ et d'alunite subtituée par l'ion oxonium $\left[\mathrm{H}_{3} \mathrm{OAl}_{2.87}\left(\mathrm{SO}_{4}\right)_{2}(\mathrm{OH})_{5.61}\left(\mathrm{H}_{2} \mathrm{O}\right)_{0.39}\right]$ au moyen de dispersion incohérente et inélastique de neutrons (IINS) afin de déterminer la nature de " $\mathrm{H}_{2} \mathrm{O}$ " autre que l'hydroxyle. Les mesures IINS ont porté sur des échantillons non-deutérés à $20 \mathrm{~K}$; elles ont été faites avec le spectromètre à sécateur HRMECS à une énergie incidente de 250 et $600 \mathrm{meV}$. Les deux matériaux répondent de façon semblable selon leurs spectres sur l'intervalle d'énergie 120-550 meV, dans lesquels les vibrations locales peuvent être assignées en fonction de la présence des groupes $\mathrm{OH}$ et $\mathrm{H}_{2} \mathrm{O}$. Les différences importantes en intensité et en position des bandes vibrationnelles observées à faible énergie témoignent des effets de la substitution chimique sur les aspects structuraux du site du cation monovalent et des sites $\mathrm{Al}$ et $\mathrm{OH}$ avoisinants dans la trame.

(Traduit par la Rédaction)

Mots-clés: alunite, dispersion inélastique des neutrons, structure cristalline, ion oxonium.

§ E-mail address: galager@louisville.edu

II Present address: Center for Mechanistic Biology and Biotechnology, Argonne National Laboratory, Argonne, Illinois 60439, U.S.A. 


\section{INTRODUCTION}

Mineral-distribution maps produced by airborne spectrometers show a strong correlation between infrared reflectance spectra and the thermal history of the alunite-jarosite minerals (Swayze 1997). Spectral absorptions in the $2-2.5 \mu \mathrm{m}$ region become more intense and broader as the temperature of formation increases, at least in Al-deficient alunite-group minerals. This spectral change, if correlated with temperature, could be used to gauge the depth of exposure in acid-sulfate deposits by remote sensing. The technique also has applications in the search for extraterrestrial life. For example, a knowledge of the level of exposure in possible Martian hydrothermal systems would be useful in the selection of those systems most likely to have sheltered life, thus providing a remote sensing tool for deciding which systems to target for lander exploration. The possibility of using these minerals as "spectral geothermometers" is dependent on our ability to correlate spectroscopic and crystallographic data, in particular, those data relating to the speciation and location of $\mathrm{H}_{2} \mathrm{O}\left[\mathrm{OH}^{-}, \mathrm{H}_{2} \mathrm{O}\right.$ and $\left.\mathrm{H}_{3} \mathrm{O}^{+}\right]$in the structure. Therefore, it is desirable to have spectroscopic data to characterize the proton dynamics in members of the alunite supergroup. Incoherent, inelastic neutron scattering (IINS) is well suited for this study because of its high sensitivity to hydrogen. Infrared and Raman spectroscopy are complementary to the IINS technique; however, the overlap of the strong $\mathrm{S}-\mathrm{O}$ bands with the characteristic bending modes for $\mathrm{H}_{3} \mathrm{O}^{+}$makes it difficult to detect the presence of $\mathrm{H}_{3} \mathrm{O}^{+}$using optical vibrational spectroscopy. In this study, IINS data have been collected at $20 \mathrm{~K}$ in order to determine the nature of the non- $\mathrm{OH}$ " $\mathrm{H}_{2} \mathrm{O}$ " in alunite and oxonium-substituted alunite [hereafter referred to $\mathrm{H}_{3} \mathrm{O}$-alunite and $\mathrm{D}_{3} \mathrm{O}$-alunite].

\section{BACKGROUND}

The structure of minerals

of the alunite-jarosite group

Minerals of the alunite-jarosite group have the general formula $M R_{3}\left(\mathrm{SO}_{4}\right)_{2}(\mathrm{OH})_{6}$, where $M$ refers to the large cation in 12-fold coordination, commonly $\mathrm{H}_{3} \mathrm{O}^{+}$, $\mathrm{Na}^{+}, \mathrm{K}^{+}, \mathrm{Rb}^{+}, \mathrm{Ag}^{+}, \mathrm{Tl}^{+}, \mathrm{NH}_{4}{ }^{+}, 1 / 2 \mathrm{~Pb}^{2+}$ or $1 / 2 \mathrm{Hg}^{2+}$, and $R$, to either $\mathrm{Al}^{3+}$ (alunite) or $\mathrm{Fe}^{3+}$ (jarosite) in octahedral coordination. The crystal structure consists of layers of corner-sharing sulfate tetrahedra and $\mathrm{RO}_{4}(\mathrm{OH})_{2}$ octahedra linked by $M$ cations (Fig. 1). The large monovalent cation site ( $m$ symmetry) has six nearest-neighbor $\mathrm{OH}$ groups and six more distant $\mathrm{O}$ atoms within its coordination sphere.

The crystal structure of alunite was first described by Hendricks (1937), who proposed the space group $R 3 m$ based on pyroelectric measurements. Wang et al. (1965) subsequently refined the structure using X-ray methods in the centrosymmetric space group $R \overline{3} m$. X- ray refinement of the crystal structures of alunite and synthetic jarosite by Menchetti \& Sabelli (1976), and a natural sample of jarosite by Kato \& Miúra (1977), provided more precise atom positions and interatomic distances. Menchetti \& Sabelli (1976) also discussed the crystal-chemical basis for the observed variation in unitcell parameters and presented indirect evidence for the existence of oxonium ion in the 12 -fold site. Szymański (1985) used X-ray diffraction to refine the crystal structure of plumbojarosite $(M=1 / 2 \mathrm{~Pb}, R=\mathrm{Fe})$, a derivative of the jarosite structure with a doubled unit-cell. Lengauer et al. (1994) have recently reported an X-ray powder refinement of the structure of a new alunitegroup compound with $M=\mathrm{K}$ and $R=\mathrm{Cr}^{3+}$. In their study, no evidence was found for a significant incorporation of the oxonium ion substituting at the 12 -fold site. A synthetic sample of stoichiometric alunite $\left[\mathrm{K}_{0.86}\left(\mathrm{D}_{3} \mathrm{O}\right)_{0.14} \mathrm{Al}_{3}\left(\mathrm{SO}_{4}\right)_{2}(\mathrm{OD})_{6}\right]$ has been investigated by Schukow et al. (1999) using neutron powder diffraction. The amount of $\mathrm{D}_{3} \mathrm{O}^{+}$in the monovalent site was found to be $12.5 \%$ based on refinement of the site-occupancy factors. The location of the $\mathrm{D}$ atoms associated with oxonium ion could not be determined.

\section{Nonstoichiometry and the presence of non-OH " $\mathrm{H}_{2} \mathrm{O}$ ”}

Numerous crystallographic and spectroscopic studies have been devoted to the nonstoichiometry and the nature of the non- $\mathrm{OH}$ " $\mathrm{H}_{2} \mathrm{O}$ " in the alunite-jarosite structure (e.g., Parker 1962, Brophy \& Sheridan 1965, Kubisz 1972, Wilkins et al. 1974, Serna et al. 1986, Ripmeester et al. 1986, Stoffregen \& Alpers 1992, Breitinger et al. 1997). Both synthetic and natural samples are known to contain $\mathrm{H}_{2} \mathrm{O}$ in excess of the stoichiometric amount. Some of the excess $\mathrm{H}_{2} \mathrm{O}$ is generally believed to be present as oxonium ion substituting for the $\mathrm{K}$ on the 12 -fold site. This interpretation is supported by a $\mathrm{K}$ deficiency in these structures, and also by the fact that the "oxonium" end-member, i.e., a compound that contains no alkali cations, can be synthesized. Members of the alunite supergroup also commonly exhibit an $R$-cation deficiency that requires conversion of some $\mathrm{OH}$ to $\mathrm{H}_{2} \mathrm{O}$ to maintain charge balance.

Ripmeester et al. (1986) have presented evidence from proton nuclear magnetic resonance (magic angle spinning) [ ${ }^{1} \mathrm{H}$ NMR MAS] spectra to support the existence of the oxonium ion. Their analyses are based to a large extent on comparisons with oxonium perchlorate, a compound in which $\mathrm{H}_{3} \mathrm{O}^{+}$is known to exist (O'Reilly et al. 1971). They proposed that the $\mathrm{D}_{3} \mathrm{O}^{+}$group is highly mobile and can assume a number of different orientations within the oxygen cage surrounding the alkali site. Analyses of the ${ }^{2} \mathrm{H}$ NMR line shapes as a function of temperature suggest that the molecular motion is temperature-dependent, i.e., the ion gradually becomes more rigid between $\sim 150$ and $77 \mathrm{~K}$, implying a dynamic, time-averaged disorder. Excess $\mathrm{D}_{2} \mathrm{O}$, beyond that required to account for $\mathrm{OD}^{-}$and $\mathrm{D}_{3} \mathrm{O}^{+}$, also was observed. 


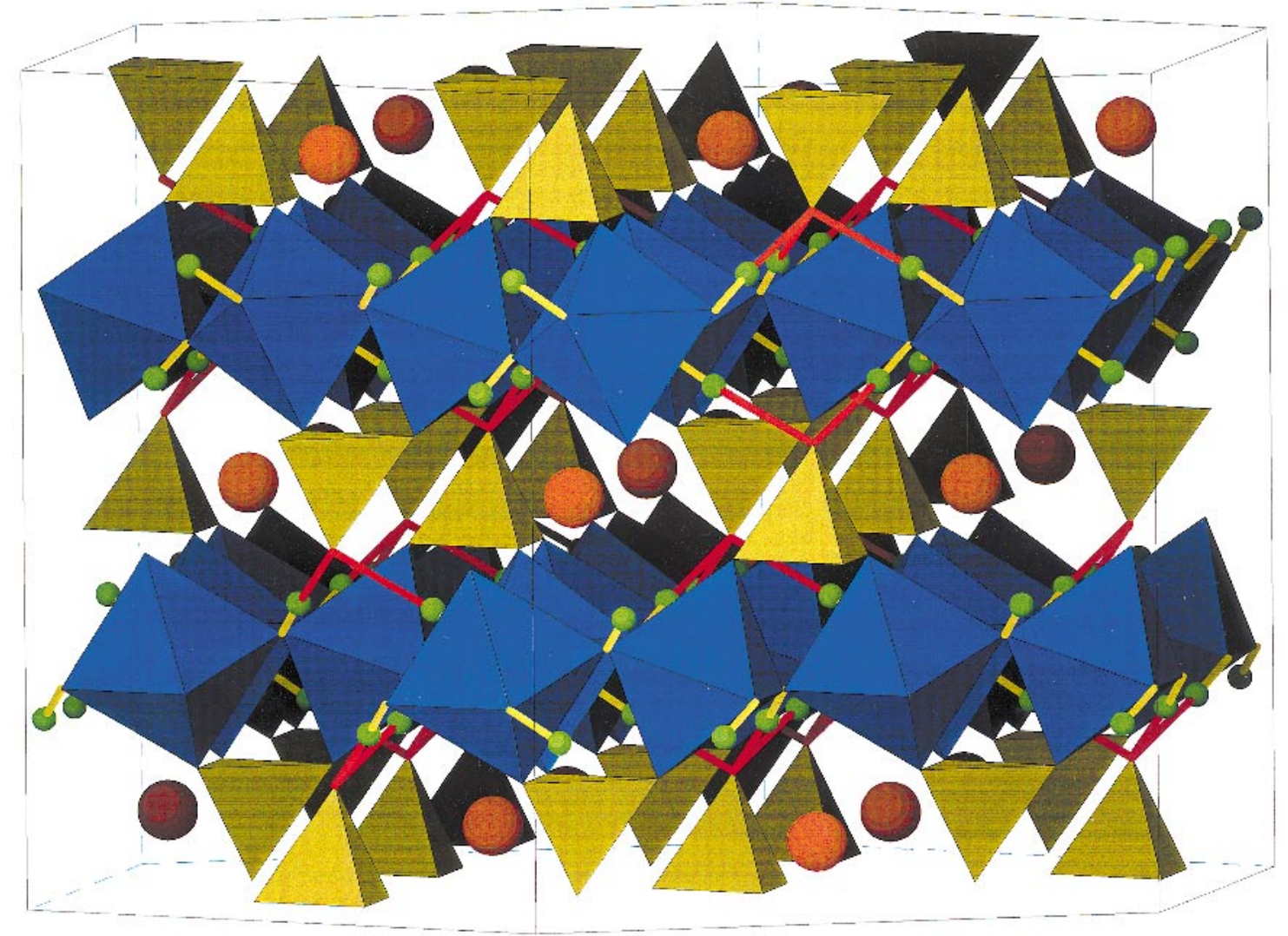

FIG. 1. Polyhedral drawing of the crystal structure of alunite viewed approximately along the [100] direction (ATOMS, version 5.0). The crystallographic $c$ axis is vertical. The small spheres represent $\mathrm{H}$ atoms, which form a trifurcated $\mathrm{H}$-bond with the O1 apical oxygen of the sulfate tetrahedron. The $M$ cations are shown as large spheres. Drawing based on fractional coordinates of atoms, from Schukow et al. (1999).

Ripmeester et al. proposed that some OD groups located adjacent to the $\mathrm{D}_{3} \mathrm{O}$ ion are converted in situ to $\mathrm{D}_{2} \mathrm{O}$ $\left[\mathrm{D}_{3} \mathrm{O}^{+}+\mathrm{OD}^{-}=2 \mathrm{D}_{2} \mathrm{O}\right]$ to compensate for charge deficiencies created by vacancies at the $\mathrm{Al}$ site. In their model, the $\mathrm{D}_{3} \mathrm{O}^{+}$ion could be partially hydrated. The molar proportions of $\mathrm{D}_{3} \mathrm{O}^{+}, \mathrm{D}_{2} \mathrm{O}$ and $\mathrm{OD}^{-}$determined from a fit of their proton NMR spectra show reasonable agreement with those determined by analytical methods in their study.

We are aware of only one preliminary IINS study of alunite (Breitinger et al. 1998), and no IINS studies of $\mathrm{H}_{3} \mathrm{O}$-substituted alunite have been reported in the literature. Neutron scattering methods have also been used to determine the proton dynamics associated with oxonium ion in aluminosilicate zeolites. Comparison of the IINS spectra of oxonium-substituted mordenite [hereafter referred to as $\mathrm{H}_{3} \mathrm{O}$-mordenite] with those of dehydrated zeolite and ice show several bands that were assigned to $\mathrm{H}_{3} \mathrm{O}^{+}$(Jobic et al. 1992). The $\mathrm{H}$ densities- of-state of $\mathrm{H}_{3} \mathrm{O}$-mordenite and mordenite- $\mathrm{Na}$ loaded at $15 \%$ relative humidity were subsequently investigated by Loong et al. (1994) at $15 \mathrm{~K}$ over a wide range of energies $(9-600 \mathrm{meV})$. Vibrational features at 59 and $155 \mathrm{meV}$ in the spectra of $\mathrm{H}_{3} \mathrm{O}$-mordenite were assigned to motion involving $\mathrm{H}_{3} \mathrm{O}^{+}$(for a comparison with optical data, $1 \mathrm{meV}$ is equivalent to $8.066 \mathrm{~cm}^{-1}$ ).

\section{EXPERIMENTAL}

\section{Sample preparation}

End-member alunite was prepared from reagentgrade $\mathrm{K}_{2} \mathrm{SO}_{4}$ and $\mathrm{Al}_{2}\left(\mathrm{SO}_{4}\right)_{3}$, combined in a ratio of $\sim 1: 2$. The latter compound was formed by heating $\mathrm{Al}_{2}\left(\mathrm{SO}_{4}\right)_{3} \cdot 18 \mathrm{H}_{2} \mathrm{O}$ at $973 \mathrm{~K}$ in air for $24 \mathrm{~h}$. The mixture was dissolved in water $\left[7 \mathrm{~g} \mathrm{~K}_{2} \mathrm{SO}_{4}+15 \mathrm{~g} \mathrm{Al}_{2}\left(\mathrm{SO}_{4}\right)_{3}\right.$ per $186 \mathrm{~mL} \mathrm{H}_{2} \mathrm{O}$ ] and heated at $423 \mathrm{~K}$ for $72 \mathrm{~h}$ in a largevolume Parr bomb fitted with a Teflon sleeve ( $86 \%$ fill). 
This method produced $\sim 10 \mathrm{~g}$ of product. In the case of $\mathrm{H}_{3} \mathrm{O}$-alunite, $\sim 8.5 \mathrm{~g}$ of $\mathrm{Al}_{2}\left(\mathrm{SO}_{4}\right)_{3}$ were dissolved in 50 $\mathrm{mL}$ of $\mathrm{H}_{2} \mathrm{O}$. In order to produce gram amounts $(\sim 2 \mathrm{~g})$ of sample, the $\mathrm{pH}$ of the solution was increased from $\sim 2.2$ to $\sim 3.5$ by the addition of reagent-grade $\mathrm{MgCO}_{3}(\sim 0.6$ $\mathrm{wt} \% \mathrm{CaO})$. After the $\mathrm{MgCO}_{3}$ was completely dissolved, the solution was heated to $473 \mathrm{~K}(72 \mathrm{~h})$ in the highvolume reaction vessel $(27 \mathrm{~mL})$ lined with a Teflon sleeve.

Results from thermogravimetric analysis (TGA) of protonated alunite and $\mathrm{H}_{3} \mathrm{O}$-alunite are shown in Figure 2. On the basis of the TGA curve, the sample (Fig. 2a) of alunite contains $\sim 19 \mathrm{wt} \% \mathrm{H}_{2} \mathrm{O}$, which exceeds the stoichiometric amount by $\sim 6 \mathrm{wt} \%$. Only a small proportion $(<1 \mathrm{wt} \%)$ of the total $\mathrm{H}_{2} \mathrm{O}$ content is present as adsorbed water. The thermal decomposition of synthetic alunite has been discussed by a number of investigators (Kubisz 1971, Fielding 1981, Pysiak \& Glinka 1981, Bohmhammel et al. 1987). The TGA curve is characterized by three well-defined stages of dehydration, which correspond, respectively, to the loss of the loosely bound $\mathrm{H}_{2} \mathrm{O}$ (i.e., the non-OH structurally bound $\mathrm{H}_{2} \mathrm{O}$ present as either $\mathrm{H}_{2} \mathrm{O}$ or $\left.\mathrm{H}_{3} \mathrm{O}^{+}\right)(\sim 548 \mathrm{~K})$, structurally bound $\mathrm{OH}(\sim 823 \mathrm{~K})$, and $\mathrm{SO}_{3}(\sim 1000 \mathrm{~K})$, produced from the breakdown of the $\mathrm{SO}_{4}$ group (Fig. 2a). In contrast to alunite, the TGA curve for $\mathrm{H}_{3} \mathrm{O}-$ alunite shows a gradual weight loss to $\sim 973 \mathrm{~K}$ (Fig. 2b). At this temperature, the structure dehydrates completely with the loss of the remaining $\mathrm{OH}$. The final weightloss at $\sim 1073 \mathrm{~K}$ reflects the release of $\mathrm{SO}_{3}$.

The results of the chemical analysis of the two samples are given in Table 1. The alunite sample was analyzed by electron microprobe using alunite from the Marysvale Christmas vein as a standard (Stoffregen \& Alpers 1992). Operating conditions of the electron microprobe were $15 \mathrm{keV}, 10 \mathrm{nA}$ with a $15 \mu \mathrm{m}$ spot size. Short count-times $(<60 \mathrm{~s})$ were necessary in order to minimize the volatilization of $\mathrm{K}$. Because of the finegrained nature of $\mathrm{H}_{3} \mathrm{O}$-alunite, the electron microprobe could not be used for this sample. In this case, the con-

TABLE 1. RESULTS OF CHEMICAL ANALYSES OF SYNTHETIC ALUNITE-GROUP PHASES

\begin{tabular}{llllllll}
\hline Sample & $\mathrm{K}_{2} \mathrm{O}$ & $\mathrm{Al}_{2} \mathrm{O}_{3}$ & $\mathrm{SO}_{3}$ & $\mathrm{H}_{2} \mathrm{O}$ & $\mathrm{Na}_{2} \mathrm{O}$ & $\mathrm{CaO}$ & Total \\
\hline $\begin{array}{c}\text { alunite (end member) } \\
\text { ideal } \\
\text { this study* }\end{array}$ & 11.38 & 36.95 & 38.65 & 13.04 & & & 100 \\
$\begin{array}{l}\mathrm{H}_{3} \mathrm{O} \text {-substituted alunite } \\
\begin{array}{l}\text { ideal } \\
\text { this study }\end{array}\end{array}$ & 10.0 & 32.3 & 38.4 & 13.04 & & & 93.7 \\
\hline
\end{tabular}

* Average result of 15 electron-microprobe analyses.

$+\mathrm{K}_{2} \mathrm{O}, \mathrm{Al}_{2} \mathrm{O}_{3}, \mathrm{Na}_{2} \mathrm{O}$ and $\mathrm{CaO}$ were determined by $\mathrm{XRF}, \mathrm{SO}_{3}$ by a Leco sulfur analyzer, and $\mathrm{H}_{2} \mathrm{O}$ by TGA. $\mathrm{Na}_{2} \mathrm{O}$ and $\mathrm{CaO}$ were introduced as impurities from $\mathrm{MgCO}_{3}$, which was used to increase the $\mathrm{pH}$ of the sulfate solution prior to hydrothermal treatment. Both samples were non-deuterated. centrations of $\mathrm{K}$ and $\mathrm{Al}$ were determined by $\mathrm{X}$-ray fluorescence (Taggert et al. 1990), and the level of $\mathrm{S}$ with a Leco sulfur analyzer and of $\mathrm{H}_{2} \mathrm{O}$ by TGA. Chemical formulae normalized on the basis of two sulfur atoms are: $\mathrm{K}_{0.88}\left(\mathrm{H}_{3} \mathrm{O}\right)_{0.12} \mathrm{Al}_{2.67}\left(\mathrm{SO}_{4}\right)_{2}(\mathrm{OH})_{4.92}\left(\mathrm{H}_{2} \mathrm{O}\right)_{1.08}$ and $\mathrm{H}_{3} \mathrm{OAl}_{2.87}\left(\mathrm{SO}_{4}\right)_{2}(\mathrm{OH})_{5.64}\left(\mathrm{H}_{2} \mathrm{O}\right)_{0.39}$. The proportion of $\mathrm{OH}$ was determined by charge balance. The $\mathrm{K}$ deficiency in alunite is less than that reported for other samples of low-temperature alunite (Stoffregen \& Alpers 1992); however, it is in good agreement with the results of atomic absorption and X-ray-fluorescence measurements carried out in this study. The low oxide total $(93.7 \%)$ for our alunite is consistent with the amount of non-stoichiometric $\mathrm{H}_{2} \mathrm{O}$ determined from TGA analysis (Fig. 2a). A small deficiency $(\sim 6 \%)$ in $\mathrm{Al}$ was observed in $\mathrm{H}_{3} \mathrm{O}$-alunite (Fielding 1981). $\mathrm{Na}, \mathrm{Mg}$ and $\mathrm{Ca}$ (from the $\mathrm{MgCO}_{3}$ ) were also detected in this sample by $\mathrm{X}$-ray fluorescence. The $\mathrm{Mg}$ is assumed to be incorporated in a small amount of amorphous material associated with the alunite and has not been reported in Table 1.

\section{Neutron-diffraction measurements}

Time-of-flight neutron powder diffraction data were collected at $295 \mathrm{~K}$ for both deuterated alunite and $\mathrm{D}_{3} \mathrm{O}$ alunite with the General Purpose Powder Diffractometer (GPPD) at the Intense Pulsed Neutron Source (IPNS), Argonne National Laboratory. The powder patterns were fitted using the Rietveld (1967) profile analysis modified for spallation-pulsed neutron sources (Von Dreele et al. 1982). Unit-cell parameters refined for both structures are in good agreement with those reported for other samples of Al-deficient alunite (Table 2). Unitcell parameters of a natural and synthetic, stoichiometric alunite also are shown in Table 2 for comparison. Results of neutron structure refinements of the deuterated alunite and $\mathrm{D}_{3} \mathrm{O}$-alunite at both ambient and low temperatures $(20 \mathrm{~K})$ provided only limited information on the nature of the non- $\mathrm{OH}$ " $\mathrm{H}_{2} \mathrm{O}$ ". In particular, deu-

TABLE 2. UNIT-CELL PARAMETERS OF SELECTED ALUNITE-GROUP PHASES (SPACE GROUP $R \overline{3} \mathrm{~m}$ )

\begin{tabular}{llllc}
\hline & $a(\AA)$ & $c(\AA)$ & $V\left(\AA^{3}\right)$ & Source \\
\hline \multirow{2}{*}{ alunite (end member) } & $7.0115(1)$ & $17.1641(3)$ & $730.76(1)$ & this study $^{\dagger}$ \\
& $7.000(2)$ & $17.180(7)$ & $729.1(4)$ & $1^{\dagger}$ \\
& $6.984(1)$ & $17.313(1)$ & $731.39(2)$ & $2^{\dagger}$ \\
& $6.986(3)$ & $17.336(23)$ & $732.7(5)$ & $3^{+}$ \\
& & & & \\
$\mathrm{H}_{3}$ O-substituted alunite & $7.0039(1)$ & $17.1258(2)$ & $727.55(1)$ & this study $^{\dagger}$ \\
& $7.005(2)$ & $17.114(7)$ & $727.2(4)$ & $1^{\dagger}$ \\
& $6.994(6)$ & $17.13(2)$ & $725.6(5)$ & $4^{\dagger}$ \\
\hline
\end{tabular}

Sources: 1 Stoffregen \& Alpers (1992), 2 Schukow et al. (1999), 3 Swayze \& Smyth, pers. commun.: high-temperature, stoichiometric alunite, Marysvale, Utah; 4 Ripmeester et aI, (1986)

${ }^{\dagger}$ deuterated. 

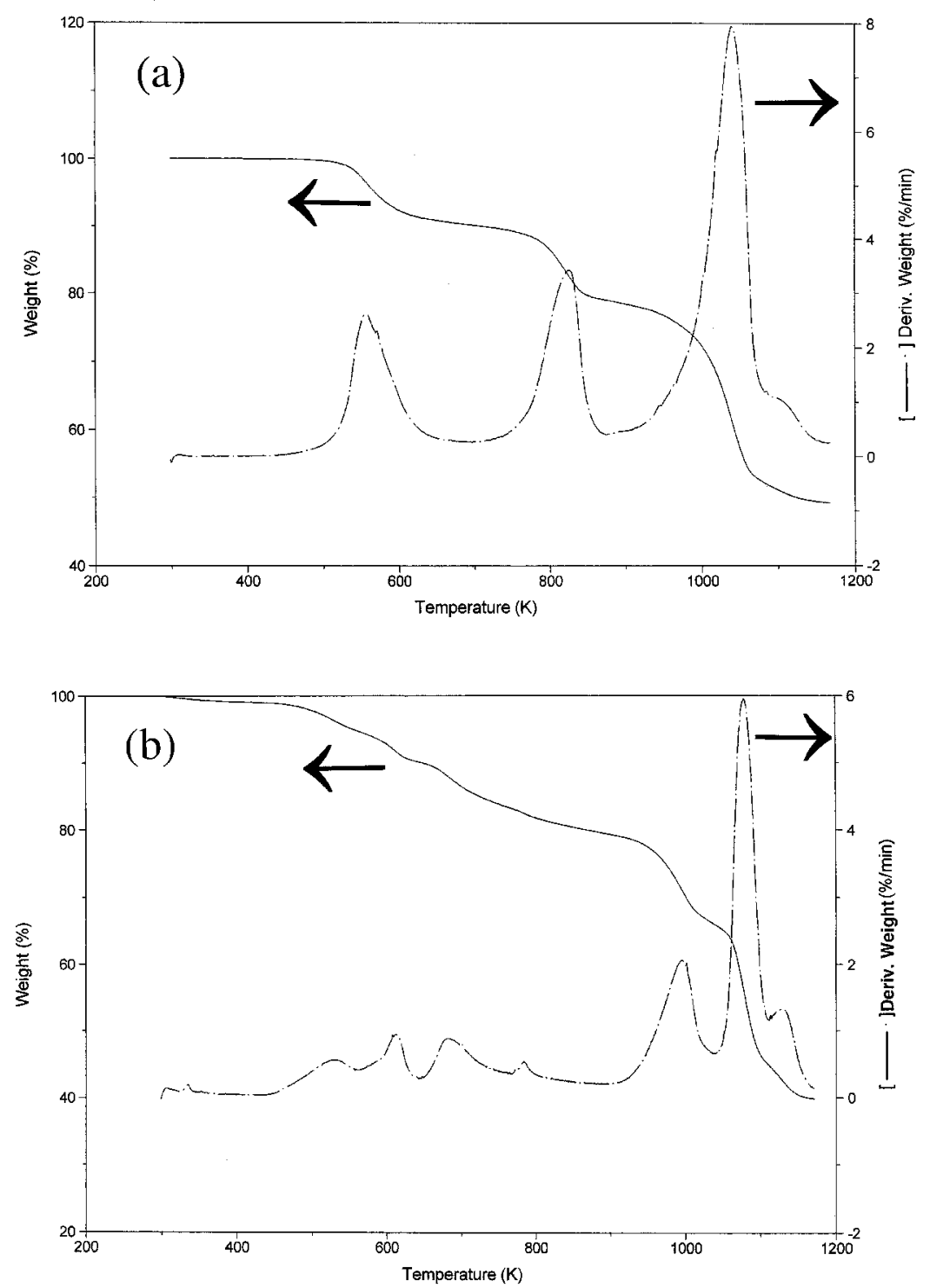

FIG. 2. Comparison of TGA curves for nonstoichiometric alunite (a), and $\mathrm{H}_{3} \mathrm{O}$-alunite (b). Data were obtained on $30-\mathrm{mg}$ samples heated at a rate of $10 \% \mathrm{~min}$ in a $\mathrm{N}_{2}$ atmosphere.

teron positions associated with $\mathrm{D}_{3} \mathrm{O}^{+}$and $\mathrm{D}_{2} \mathrm{O}$ were difficult to locate from diffraction data because of the disorder.

\section{Measurements of inelastic neutron-scattering}

The atomic dynamics in members of the alunite supergroup were studied by inelastic-scattering experiments using the High-Resolution Medium-Energy
Chopper Spectrometer (HRMECS) at IPNS. A pulsedneutron source like IPNS, equipped with cold moderators, provides a large flux of cold-to-epithermal neutrons that are essential to study the low-energy lattice modes as well as the high-energy molecular vibrations. In general, the energy resolution $\Delta \mathrm{E}$ (full width at half-maximum) of the HRMECS spectrometer varies from $4 \%$ of the incident energy $\left(\mathrm{E}_{0}\right)$ in the elastic region to $2 \%$ near the end of the neutron energy-loss spectrum. The 
powder $\left(\sim 10\right.$ and $\sim 30 \mathrm{~g}$ of $\mathrm{H}_{3} \mathrm{O}$-alunite and alunite, respectively) was placed inside a sealed aluminum container in the shape of a thin slab (dimension $7.5 \times 100$ $\times 2 \mathrm{~mm}^{3}$ ) mounted to the cold plate of a closed-cycle helium refrigerator at a $45^{\circ}$ angle to the incident beam of neutrons. Such a geometry reduces as much as possible the multiple-scattering effects. In order to minimize multiple scattering of phonons, the sample was cooled to $\sim 20 \mathrm{~K}$. Background scattering was subtracted from the data by using an empty-container run. Measurements of elastic incoherent scattering from a vanadium standard provided detector calibration and intensity normalization. Two incident energies, 600 and $250 \mathrm{meV}$, were used in order to characterize the energy spectra from 0 to $550 \mathrm{meV}$ with good resolution.

Owing to the spin incoherence of the proton, the neutron scattering cross-section of hydrogen is predominantly incoherent, which is ideal for probing the singleparticle motions of hydrogen atoms associated with atomic migrations, lattice and localized vibration without being subject to any selection rules. The incoherent scattering function for lattice and local vibrations (phonons) of atoms in a harmonic solid is given by

$$
\begin{gathered}
S(Q, E)=\sum_{\mathrm{i}} \frac{c_{\mathrm{i}} \sigma_{\mathrm{i}}}{m_{\mathrm{i}}} \\
\left\langle(\mathbf{Q} \cdot \mathbf{e})^{2} e^{-2 W_{\mathrm{i}}(Q)}\right\rangle \frac{n(E)+1}{E} F_{\mathrm{i}}(E),
\end{gathered}
$$

where $c_{i}, \sigma_{i}, m_{i}, \mathbf{e}_{i}, e^{-2 W_{i}(Q)}$, and $F_{i}$ are the concentration, incoherent scattering cross-section, mass, phonon unitpolarization vector, Debye-Waller factor, and partial phonon density of states, respectively, for the th atom. The quantity $(\hbar \mathbf{Q}, E)$ corresponds to the momentum and energy transfer of the neutron, respectively ( $\hbar$ being Planck's constant), and $n(E)$ is the Bose thermal occupational factor (Price \& Sköld 1986). At low temperatures and high energies the thermal factor, $n(E)+1$ is approximately equal to 1 . The quantity enclosed in the angular brackets $\langle\ldots\rangle$ is averaged over all modes with the energy $E$ and, for polycrystalline materials, it is effectively averaged over all $\mathbf{Q}$ directions. The ratios $\sigma_{i} /$ $m_{i}$ for $\mathrm{K}, \mathrm{O}, \mathrm{S}, \mathrm{Al}$ and $\mathrm{H}$ are $0.0658,0.265,0.0320$, 0.0557 , and $81.7 \mathrm{~b} / \mathrm{amu}$, respectively for thermal neutrons $\left(1 \mathrm{~b}=10^{-24} \mathrm{~cm}^{2}\right.$, and amu refers to atomic mass units). Therefore, the scattering function is particularly sensitive to hydrogen vibrations and effectively provides a measure of the hydrogen vibrational density of states. The scattering function given below was obtained from an average over the $\mathbf{Q}$ values corresponding to scattering angles of $4^{\circ}$ to $20^{\circ}$. Such a low-Q region is needed in order to avoid significant Doppler broadening of the inelastic features at high-momentum transfers, which is most significant for hydrogen motion. The observed low- and high-energy neutron-scattering functions for alunite and $\mathrm{H}_{3} \mathrm{O}$-alunite at $20 \mathrm{~K}$, obtained from 250 and $600 \mathrm{meV}$ runs, respectively, are compared in Figure 3.

\section{Results AND Discussion}

In general, the IINS spectra of the two samples of alunite can be divided into a high-energy (160-550 $\mathrm{meV}$ ) and a low-energy (20-160 $\mathrm{meV}$ ) region, which relate primarily to hydrogen vibrations involving localized motion and collective modes associated with neighboring atoms or framework units, respectively. The high-energy spectra of alunite and $\mathrm{H}_{3} \mathrm{O}$-alunite are similar, whereas marked differences can be seen at low energies (Fig. 3).

The bands at about 200 and $430 \mathrm{meV}$ are characteristic of $\mathrm{H}-\mathrm{O}-\mathrm{H}$ bending and $\mathrm{O}-\mathrm{H}$ stretch vibrations of $\mathrm{H}_{2} \mathrm{O}$ or $\mathrm{H}_{3} \mathrm{O}$ species (or both), and that at $\sim 510 \mathrm{meV}$ is a combination mode (Loong et al. 1987). The band

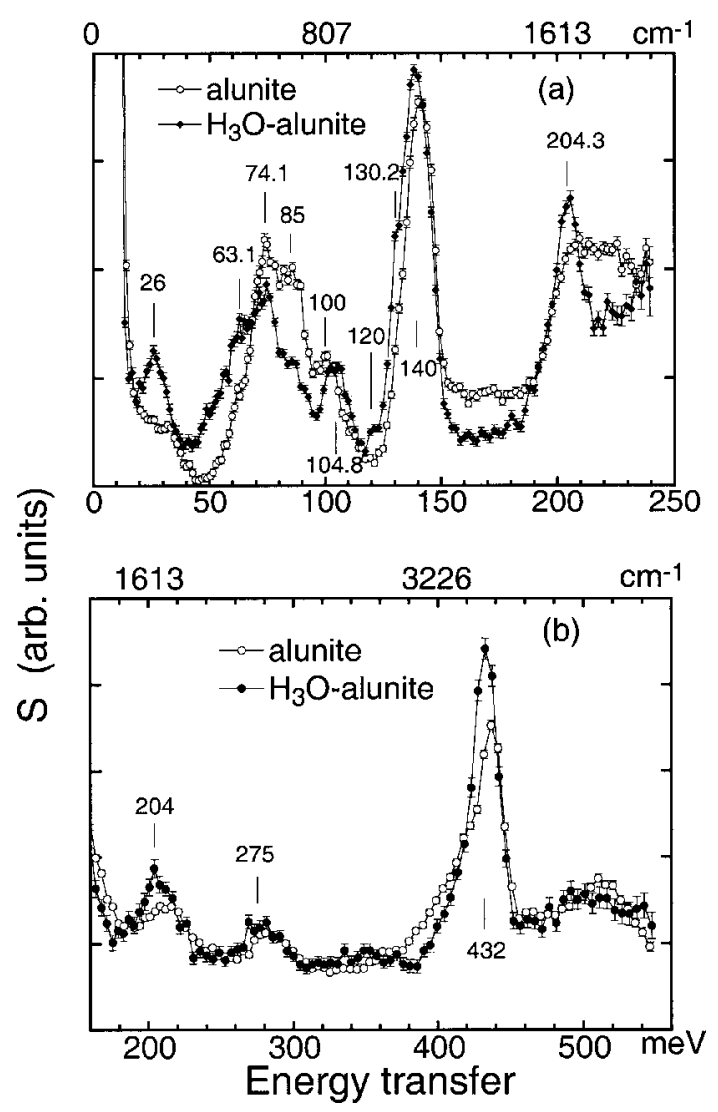

FIG. 3. Comparison of the observed low- and high-energy neutron scattering functions for alunite and $\mathrm{H}_{3} \mathrm{O}$-alunite obtained at $20 \mathrm{~K}$ from the 250 (a) and $600 \mathrm{meV}$ (b) runs. Major vibrational bands are labeled in units of $\mathrm{meV}$, where $1 \mathrm{meV}=8.066 \mathrm{~cm}^{-1}$. 
around $280 \mathrm{meV}$ is an overtone of the $140 \mathrm{meV}$ band. In this region of the spectrum, we do not expect large differences in the $\mathrm{O}-\mathrm{H}$ stretch frequencies between $\mathrm{H}_{2} \mathrm{O}$ and $\mathrm{H}_{3} \mathrm{O}^{+}$because these species have very similar $\mathrm{O}-\mathrm{H}$ bond lengths. The most obvious difference is the asymmetric shape at the lower-energy side of the $\mathrm{OH}$ band in alunite, which suggests a stronger network of $\mathrm{H}$-bonds. This is consistent with the conversion of some $\mathrm{OH}$ to $\mathrm{H}_{2} \mathrm{O}$ in alunite in order to compensate for the charge imbalance created by vacancies at the $\mathrm{Al}$ site. By choosing an incident energy of $250 \mathrm{meV}$ (Fig. 3a), the resolution $(\Delta \mathrm{E}=5 \mathrm{meV})$ for $\mathrm{E}>200 \mathrm{meV}$ is sufficient to resolve the narrow width of the $\mathrm{H}-\mathrm{O}-\mathrm{H}$ bending mode $(\sim 204 \mathrm{meV})$ in $\mathrm{H}_{3} \mathrm{O}$-alunite. The corresponding peak in alunite, on the other hand, exhibits considerable broadening. This effect indicates that the force fields relevant to $\mathrm{H}-\mathrm{O}-\mathrm{H}$ bending are more uniform in $\mathrm{H}_{3} \mathrm{O}$-alunite, presumably owing to long-range structural correlations arising from $\mathrm{H}$-bonding.

The low-energy spectrum of alunite differs considerably from that of the $\mathrm{H}_{3} \mathrm{O}$-substituted analog. The strong peak at $\sim 140 \mathrm{meV}$, which can be assigned to $\mathrm{OH}-$ librations $\left[\delta_{Z}(\mathrm{OH})\right.$ modes], is narrower in alunite. The corresponding peak in $\mathrm{H}_{3} \mathrm{O}$-alunite shifts slightly toward lower energy and shows small shoulders at $\sim 130$ and $120 \mathrm{meV}$. The broad band from 60 to $120 \mathrm{meV}$ in alunite can be assigned to $\mathrm{Al}-\mathrm{OH}$ and $\mathrm{S}-\mathrm{OH}$ motion and $\mathrm{OH}-$ hindered rotations (Serna et al. 1986, Breitinger et al. 1997). This band is wider and its substructure is different in $\mathrm{H}_{3} \mathrm{O}$-alunite. In both samples, the highest intensity sub-peak is located at $74.1 \mathrm{meV}$. However, the relative intensities of the side peaks ( $\sim 63$ and $\sim 85 \mathrm{meV}$ ) are inversely related in the two samples. Finally, the band at $\sim 26 \mathrm{meV}$ is much more pronounced in the $\mathrm{H}_{3} \mathrm{O}$ alunite than in alunite.

Despite the lower resolution at low-energy transfers, features in the HRMECS spectrum of alunite agree well with the IINS spectrum of a sample of alunite of nominal composition $\mathrm{KAl}_{3}(\mathrm{OH})_{6}\left(\mathrm{SO}_{4}\right)_{2}$ measured by an inverse-geometry spectrometer (TFXA) at the ISIS facility (Breitinger et al. 1998).

One of the objectives of this study was to determine if oxonium ions occupy the monovalent cation site. Obviously, if structural differences between alunite and $\mathrm{H}_{3} \mathrm{O}$-alunite are related simply to oxonium content, we would expect a much different spectrum for $\mathrm{H}_{3} \mathrm{O}$ alunite, i.e., it should show additional features that can be attributed to the vibrations of the oxonium ion. For example, in the case of $\mathrm{H}_{3} \mathrm{O}$-substituted mordenite, bands at about 172 and $207 \mathrm{meV}$ were assigned to the symmetric and antisymmetric bending modes of oxonium ions (Jobic et al. 1992). In a similar study, Loong et al. (1994) compared the IINS spectra of $\mathrm{H}_{3} \mathrm{O}-$ mordenite $\left[\mathrm{H}\left(\mathrm{H}_{3} \mathrm{O}\right) / \mathrm{H}\left(\mathrm{H}_{2} \mathrm{O}\right) \approx 1\right]$ and mordenite-Na $\left(\mathrm{H}_{3} \mathrm{O}\right.$-free). Two small peaks at 59 and $155 \mathrm{meV}$ in $\mathrm{H}_{3} \mathrm{O}-$ mordenite were attributed to oxonium. Distinct peaks corresponding to the presence of oxonium were not observed in the alunite samples. However, as pointed out previously, spectroscopic features that reflect a difference in the oxonium content in the samples are expected to occur in the low-energy portion of the spectrum. In fact, we observed significant differences in all the major bands from about 20 to $120 \mathrm{meV}$. However, these differences may arise not only from the presence of oxonium, but also from a complex modification of the structure related to substitutions involving the monovalent $\left[\mathrm{K}=\mathrm{H}_{3} \mathrm{O}\right]$, octahedral $[\mathrm{Al}=$ vacancy $]$ and $\mathrm{OH}$ sites $\left[\mathrm{OH}=\mathrm{H}_{2} \mathrm{O}\right]$.

One possible interpretation of the neutron data is that there are no oxonium ions present in these particular samples, because no new peaks were observed in the spectrum of $\mathrm{H}_{3} \mathrm{O}$-alunite. However, this conclusion is based on a comparison of IINS spectra for alunite and $\mathrm{H}_{3} \mathrm{O}$-mordenite, a zeolite. The environment of oxonium is quite different in these two structures. As noted above, the oxonium ion in alunite would occupy the 12-coordinated monovalent site, with $\overline{3} m$ symmetry. In mordenite, oxonium is associated with a framework oxygen and has no symmetry constraints. Therefore, we suggest that oxonium may exist in alunite-group phases, but the present data, based on a comparison of the spectra of the alunite and its $\mathrm{H}_{3} \mathrm{O}$-substituted analog at low energytransfers, cannot distinguish oxonium from hydroxyl groups and $\mathrm{H}$-bonded $\mathrm{H}_{2} \mathrm{O}$ molecules in such a complex structure. The question concerning the nature of the non- $\mathrm{OH}$ " $\mathrm{H}_{2} \mathrm{O}$ " can be addressed, in principle, if data from neutron, optical and NMR spectroscopy are analyzed by rigorous numerical simulations.

\section{ACKNOWLEDGEMENTS}

This work has benefitted from use of the Intense Pulsed Neutron Source at Argonne National Laboratory. This facility is funded by the U.S. Department of Energy, BES-Materials Science, under contract W-31109-Eng-38. The authors thank L.A. Groat for carrying out the electron-microprobe analysis of the synthetic alunite. Comments by D.K. Breitinger, C. McCammon and an anonymous reviewer significantly improved the manuscript.

\section{REFERENCES}

Bohmhammel, K., Naumann, R. \& Paulik, F. (1987): Thermoanalytical and calorimetric investigations on the formation and decomposition of some alunites. Thermochim. Acta 121, 109-119.

Breitinger, D.K., Krieglstein, R., Bogner, A., Schwab, R.G., Pimpl, T.H., Mohr, J. \& SchuKow, H. (1997): Vibrational spectra of synthetic minerals of the alunite and crandallite type. J. Mol. Struct. 408/409, 287-290.

Schwab, R.G., Mohr, J. \& Tomkinson, J. (1998): ISIS 98. ISIS Facility Annual Report 1997-98, RB 9392. 
BRophy, G.P. \& SHERIDAN, M.F. (1965): Sulfate studies. IV. The jarosite - natrojarosite - hydronium jarosite solid solution series. Am. Mineral. 50, 1595-1607.

FIELding, S.J. (1981): Crystal Chemistry of the Oxonium Alunite - Potassium Alunite Series. M.S. thesis, Lehigh Univ., Bethlehem, Pennsylvania.

HENDRICKS, S.B. (1937): The crystal structure of alunite and the jarosites. Am. Mineral. 22, 773-784.

Jobic, H., CzJZEK, M. \& VAN SANTEN, R.A. (1992): Interaction of water with hydroxyl groups in H-mordenite: a neutron inelastic scattering study. J. Phys. Chem. 96, 1540-1542.

KATO, T. \& MiÚRA, Y. (1977): The crystal structures of jarosite and svanbergite. Mineral. J. 8, 419-430.

Kubisz, J. (1971): Studies on synthetic alkali-hydronium jarosites. II. Thermal investigations. Mineral. Polonica 2, 51-60.

(1972): Studies on synthetic alkali-hydronium jarosites. III. Infrared absorption study. Mineral. Polonica 3, 23-35.

Lengauer, C.L., Giester, G. \& IRRAN, E. (1994): $\mathrm{KCr}_{3}\left(\mathrm{SO}_{4}\right)_{2}$ $(\mathrm{OH})_{6}$ : synthesis, characterization, powder diffraction data, and structure refinement by Rietveld technique and a compilation of alunite-type compounds. Powder Diffr. 9, 265271.

LoONG, C.-K., IKEDA, S. \& CARPENTER, J.M. (1987): The resolution function of a pulsed-source neutron chopper spectrometer. Nucl. Instrum. Methods A260, 381-402.

Trouw, F. \& ITon, L.E. (1994): Formic acid, ethanol in Vycor glass, and water in aluminosilicate zeolites. In Hydrogen Bond Networks (M.-C. Bellissent-Funel \& J.C. Dore, eds.). Kluwer Academic Publishers, Dordrecht, The Netherlands (231-238)

Menchetti, S. \& Sabelli, C. (1976): Crystal chemistry of the alunite series: crystal structure refinement of alunite and synthetic jarosite. Neues Jahrb. Mineral., Monatsh., 406-417.

O’Reilly, D.E., Peterson, E.M. \& Williams, J.M. (1971): Nuclear magnetic resonance of the aquated proton: hydronium perchlorate. J. Chem. Phys. 54, 96-98.

PARKER, R.L. (1962): Isomorphous substitution in natural and synthetic alunite. Am. Mineral. 47, 127-136.

PRICE, D.L. \& SKÖLD, K. (1986): Introduction to neutron scattering. In Neutron Scattering A (K. Sköld \& D.L. Price, eds.). Academic, Orlando, Florida (29-97).
Pysiak, J. \& GlinkA, A. (1981): Thermal decomposition of basic aluminum potassium sulfate. I. Stages of decomposition. Thermochim. Acta 44, 21-28.

RIETVELD, H.M. (1967): Line profiles of neutron powder-diffraction peaks for structure refinement. Acta. Crystallogr. 22, 151-152.

RIPMEESTER, J.A., RATCLIFFe, C.I., DUTRIZAC, J.E. \& JAMbOR, J.L. (1986): Hydronium ion in the alunite-jarosite group. Can. Mineral. 24, 435-447.

Schukow, H., Breitinger, D.K., Zeiske, T., Kubanek, F., MoHR, J. \& SchwAB, R.G. (1999): Localization of hydrogen and content of oxonium cations in alunite via neutron diffraction. Z. Anorg. Allg. Chem. 625, 1047-1050.

Serna, C.J., Cortina, C.P. \& Garcia Ramos, J.V. (1986): Infrared and Raman study of alunite-jarosite compounds. Spectrochim. Acta 42A, 729-734.

Stoffregen, R. \& AlPers, C.N. (1992): Observations on the unit-cell dimensions, $\mathrm{H}_{2} \mathrm{O}$ contents, and $\delta \mathrm{D}$ values of natural and synthetic alunite. Am. Mineral. 77, 1092-1098.

SwAYZE, G.A. (1997): The Hydrothermal and Structural History of the Cuprite Mining District, Southwestern Nevada: an Integrated Geological and Geophysical Approach. $\mathrm{Ph} . \mathrm{D}$. Dissertation, Univ. of Colorado, Boulder, Colorado.

SZYMANSKI, J.T. (1985): The crystal structure of plumbojarosite $\mathrm{Pb}\left[\mathrm{Fe}_{3}\left(\mathrm{SO}_{4}\right)_{2}(\mathrm{OH})_{6}\right]_{2}$. Can. Mineral. 23, 659-668.

Taggert, J.E., Jr., Bartel, A. \& Siems, D.F. (1990): High precision major element analysis of rocks and minerals by wavelength dispersive X-ray fluorescence spectroscopy. In Quality Assurance Manual for the Branch of Geochemistry0 (B.F. Arbogast, ed.). U.S. Geol. Surv., Open-File Rep. 090-0688, 166-172.

Von DREele, R.B., JoRgENSEN, J.D. \& WindSOR, C.G. (1982): Rietveld refinement with spallation neutron powder diffraction data. J. Appl. Crystallogr. 15, 581-589.

Wang, Rong, Bradley, W.F. \& Steinfink, H. (1965): The crystal structure of alunite. Acta Crystallogr. 18, 249-252.

Wilkins, R.W.T., Mateen, A. \& West, G.W. (1974): The spectroscopic study of oxonium ions in minerals. Am. Mineral. 59, 811-819.

Received September 28, 2000, revised manuscript accepted July 7, 2001. 